\title{
Deteksi Perubahan Citra Pada Video Menggunakan Illumination Invariant Change Detection
}

\author{
Adri Priadana*1, Agus Harjoko ${ }^{2}$ \\ ${ }^{1}$ Mahasiswa Program Studi S2 Ilmu Komputer, FMIPA UGM, Yogyakarta \\ ${ }^{2}$ Staf Pengajar Program Studi S2 Ilmu Komputer, FMIPA UGM, Yogyakarta \\ e-mail: *11adripriadana3202@gmail.com, ${ }^{2}$ aharjoko@ugm.ac.id
}

\begin{abstract}
Abstrak
Pada masa modern ini masih banyak terdapat kenakalan remaja di tengah-tengah masyarakat khususnya masyarakat di daerah perkotaan. Kenakalan remaja dapat berupa perkelahian, balapan liar, perjudian, dan coret-coret di dinding tanpa ijin. Aksi corat-coret dinding biasanya dilakukan pada dinding-dinding bangunan perkantoran dan pada properti publik atau swasta. Hasil dari aksi corat-coret dinding dapat diketahui dari perubahan citra antara citra awal dengan citra setelah adanya sebuah gerakan.

Penelitian ini mengembangkan sebuah sistem deteksi perubahan citra pada video untuk mendeteksi aksi corat-coret pada dinding melalui sebuah kamera Closed Circuit Television (CCTV) diamana dilakukan secara simulasi dengan menggunakan kamera webcam. Proses deteksi gerak dilakukan dengan metode Accumulative Differences Images (ADI) dan proses deteksi perubahan citra dilakukan dengan metode Illumination Invariant Change Detection ditambah dengan metode Cropping citra dimana hasilnya dilakukan perbandingan antara citra referensi atau citra sebelum ada gerakan dengan citra setelah ada gerakan.

Pengujian sistem dilakukan pada beberapa kondisi waktu yang berbeda yaitu pada pagi, siang, sore, dan malam hari. Metode yang diajukan untuk sistem deteksi perubahan citra pada video memberikan hasil dengan tingkat akurasi $92.86 \%$.
\end{abstract}

Kata kunci-Deteksi Gerak, ADI, Deteksi Perubahan Citra,IlluminationInvariant

There is still a lot of juvenile delinquency in the middle of the community, especially people in urban areas, in the modern era. Juvenile delinquency may be fights, wild racing, gambling, and graffiti on the walls without permission. Vandalized wall is usually done on walls of office buildings and on public or private property. Results from vandalized walls can be seen from the image of the change between the initial image with the image after a motion.

This study develops a image change detection system in video to detect the action of graffiti on the wall via a Closed-Circuit Television camera (CCTV) which is done by simulation using the webcam camera. Motion detection process with Accumulative Differences Images (ADI) method and image change detection process with Illumination Invariant Change Detection method coupled with image cropping method which carried out a comparison between the a reference image or image before any movement with the image after there is movement.

Detection system testing one by different times variations, ie in the morning, noon, afternoon, and evening. The proposed method for image change detection in video give results with an accuracy rate of $92.86 \%$.

Keywords—Motion Detection, ADI, Image Change Detection, Illumination Invariant

Received December 29 $9^{\text {th }}, 2016$; Revised January $31^{\text {th }}$, 2017; Accepted January $31^{\text {th }}, 2017$ 


\section{PENDAHULUAN}

$\mathrm{P}$ ada masa modern ini masih banyak terdapat kenakalan remaja di tengah-tengah masyarakat khususnya masyarakat di daerah perkotaan. Kenakalan remaja meliputi semua perilaku yang menyimpang dari norma, aturan, atau hukum dalam masyarakat yang dilakukan oleh remaja. Kenakalan remaja dapat berupa perkelahian, balapan liar, perjudian, dan coret-coret di dinding tanpa izin. Aksi corat-coret dinding yang dilakukan oleh remaja tidak selamanya buruk. Jika dikerjakan dengan terkonsep, hasilnya akan menjadi salah satu saluran ekspresi dan karya seni yang sangat indah dipandang. Namun aksi corat-coret dinding yang dilakukan tanpa seizin pemilik objek adalah tindakan yang melanggar aturan dan bersifat ilegal. Aksi corat-coret biasanya dilakukan pada dinding-dinding bangunan perkantoran dan pada properti publik atau swasta. Dinding yang pada awalnya bersih menjadi kotor dengan adanya corat-coretan.

Melihat dari masalah yang ditimbulkan dari aksi corat-coret dinding, sangat diperlukan upaya-upaya untuk mengatasi atau setidaknya mengawasi tindakan corat-coret dinding pada tempat-tempat umum. Salah satu upaya yang dilakukan saat ini adalah dengan melakukan patroli oleh petugas keamanan setiap waktu secara rutin pada tempat-tempat umum yang dirasa sangat riskan terjadi aksi corat-coret. Namun hal ini tentunya membutuhkan biaya dan sumber daya manusia yang tidak sedikit.

Hasil dari aksi corat-coret dinding dapat diketahui dari perubahan citra antara citra awal dengan citra setelah adanya sebuah gerakan. Aksi corat-coret dinding dapat bersifat legal atapun ilegal. Tergantung dari aksi corat-coret tersebut apakah memiliki izin dari pemilik proeprti atau tidak. Aksi corat-coret yang memiliki izin dari pemilik properti adalah bersifat legal, sedangkan aksi corat-coret yang tidak memiliki izin dari pemilik properti adalah bersifat ilegal dan dapat disebut sebagai vandalisme. Penelitian ini mengembangkan sebuah sistem untuk mengawasi dinding yang dianggap rawan terjadi coretan tanpa izin melalui sebuah kamera Closed Circuit Television (CCTV) sehingga dapat mendeteksi perubahan citra yang di duga sebagai aksi coratcoret dinding dan memberikan sebuah peringatan sedini mungkin.

Pembangunan sistem deteksi pada penelitian ini melibatkan beberapa proses yaitu deteksi gerak dan deteksi perubahan citra. Proses deteksi gerak dilakukan dengan metode Accumulative Differences Images (ADI) dimana dilakukan pada area spasial yaitu membandingkan perbedaan citra pada beberapa frame yang berurutan dari video [1]. Jika dibandingkan dengan metode yang hanya membandingkan perbedaan antara dua frame pada setiap prosesnya, metode ADI dinilai dapat mengurangi error karena diambil dari hasil nilai akumulasi pergerakan dari beberapa frame.

Proses deteksi perubahan citra dilakukan dengan metode Illumination Invariant Change Detection dimana dilakukan perbandingan antara citra awal atau citra sebelum ada gerakan dengan citra setelah ada gerakan. Metode ini dipilih karena untuk mendeteksi perubahan citra hampir tidak terpengaruh oleh perubahan pencahayaan (illumination).Sehingga diharapkan pencahayaan yang disajikan sistem tidak memiliki pengaruh terhadap kemampuan sistem untuk mendeteksi perubahan antara citra awal dengan citra setelah ada gerakan.Sistem akan dilakukan evaluasi dengan menggunakan perhitungan precision, recall, dan akurasi. Adapun rumus dari precision, recall, dan akurasi dapat ditunjukkan rumus 1, rumus 2 dan rumus 3 [2]

$$
\begin{aligned}
& \text { precision }=\frac{T P}{T P+F P} \\
& \text { recall }=\frac{T P}{T P+F N} \\
& \text { akurasi }=\frac{T P+T N}{T P+T N+F P+F N}
\end{aligned}
$$

Adapun TP adalah True Positif, TN adalah True Negatif, FP adalah False Positif, dan FN adalah False Negatif.

IJCCS Vol. 11, No. 1, January 2017 : $89-98$ 
Metode yang diusulkan untuk mendeteksi gerakan pada penelitian ini yaitu metode Accumulative Differences Images (ADI). Metode ADI tersebut telah digunakan oleh beberepa penelitian sebelumnya. Cappelletta dan Harte melakukan penelitian yaitu deteksi lubang hidung untuk pelacakan pergerakan mulut yang handal dalam Audio-Visual Speech Recognition (AVSR) dengan mengkombinasikan metode ADI dengan nostril detection dimana memberikan hasil pelacakan yang lebih halus dari ucapan mulut [3].

Kondo melakukan penelitian tentang metode ekstraksi obyek yang bergerak menggunakan intensitas akumulatif dan perbedaan tekstur, menggunakan metode ADI sebagai dasarnya [4].Dari hasil penelitian tersebut didapatkan bahwa metode ADI berbasis intensitas konvensional dapat bekerja dengan baik dalam kondisi pencahayaan yang konstan. Metode ADI juga dapat mengatasi masalah false detection dari ketidak tepatan detail citra seperti tepian dan garis.

Pada penelitian yang akan diusulkan ini, peneliti juga mencoba menerapkan metode yang lain untuk deteksi perubahan citra yaitu Illumination Invariant Change Detection untuk mendeteksi aksi vandalisme berupa coretan pada dinding. Menurut Toth, Aach dan Metzler metode tersebut dapat mendeteksi perubahan citra dengan hampir tidak terpengaruh oleh perubahan pencahayaan (illumination) yang didasarkan pada teknik homomorphic filtering [5]. Terdapat sebuah penelitian yang menunjukkan bahwa metode Illumination Invariant Change Detection memiliki ketahanan yang besar terhadap perubahan pencahayaan yang dilakukan oleh Liu, Sun, dan Sclabassi [6]. Pada penelitiannya, peneliti mengusulkan metode tersebut untuk membangun sistem video untuk keperluan patient caring dan monitoring.Penelitian tersebut menyimpulkan bahwa metode Illumination-Invariant Change Detection yang diusulkan memiliki ketahanan yang baik terhadap perubahan pencahayaan.

Penelitian lain yang membahas tentang corat-coret dinding yang bersifat ilegal atau dapat disebut aksi vandalisme telah dilakukan oleh beberapa peneliti sebelumnya. Penelitian oleh Sacchi, Regazzoni, dan Vernazza dilakukan dengan mendeteksi dan melakukan tracking pada beberapa area yang bergerak pada scene yang dipantau untuk membangun struktur data yang disebut blob graph, dimana mampu mendeskripsikan perubahan dinamis dari masing-masing lintasan blob yang terdeteksi pada sebuah scene [7]. Pendekatan yang dilakukan oleh peneliti menghasilkan sistem dengan akurasi deteksi vandalisme berupa graffiti yang benar sebesar $84.21 \%$, false alarm sebesar $10.53 \%$ dan misdetection sebesar $5.26 \%$, namun penelitian tersebut tidak dijelaskan bagaimana kemampuan sistem terhadap perubahan pencahayaan pada area pengawasan.

Penelitian oleh Angiati, Gera, Piva dan Regazzoni dilakukan dengan mendeteksi pelaku vandalisme berupa graffiti sebagai seseorang yang akan melukis pada dinding [8]. Selain itu sistem tidak menandai pelaku vandalisme dengan sebuah bounding box. Untuk tujuan tersebut, dilakukan pra-processing yaitu Low-Level Image Processing (LLIP) dan High-Level Image Processing (HLIP). LLIP bertujuan untuk membedakan antara gambar graffiti dan penulis.Ide utamanya adalah membagi citra pada dua area, yang pertama citra yang menunjukan obyek yang bergerak (blob moving) dan yang kedua citra yang permanen. Untuk melakukan hal ini, Mean Change Detection (MCD) image digunakan. Dari kedua citra tersebut, HLIP diterapkan untuk mendeteksi blobs dan membedakan objek yang berdiri dan orang yang bergerak. Dengan cara ini sistem mampu mendeteksi graffiti dan mengidentifikasinya dari orang yang membuatnya. Pada penelitian ini percobaan dilakukan pada siang dan malam hari.Pendekatan yang dilakukan oleh peneliti menghasilkan sistem dengan akurasi deteksi vandalisme berupa graffiti yang benar pada siang hari sebesar $97 \%$ dan pada malam hari sebesar $95 \%$.

Penelitian hampir serupa juga dilakukan oleh Ghazal, Vazquez, dan Amer yang mengusulkan sebuah metode untuk mendeteksi aksi perusakan (vandalisme) pada video pengawasan secara real time[9]. Deteksi vandalisme dilakukan dengan mengekstraksi kejadian tanpa perlu pengenalan obyek.Penelitian tersebut menguji metode yang diusulkan secara online dan offline dan hasil penelitiannya menunjukkan bahwa metode tersebut dapat mendeteksi vandalisme dan membedakan antara tindakan yang normal dengan tindakan yang bersifat merusak (vandalisme). 


\section{METODE PENELITIAN}

Proses deteksi perubahan citra pada video yang akan dilakukan pada penelitian ini meliputi dua subproses yaitu proses deteksi gerak denan metode ADI dan deteksi perubahan citra dengan metode Illumination Invariant Change Detection yang dikombinasikan dengan metode cropping citra untuk membatasi wilayah pengamatan. Pada sistem ini terdapat dua proses deteksi gerak. Proses deteksi gerak yang pertama bertujuan untuk mendeteksi gerakan pada video. Proses deteksi gerak yang kedua adalah untuk mendeteksi bahwa gerakan sudah tidak ada lagi. Setelah itu akan dilakukan proses deteksi perubahan citra yang dikombinasikan dengan metode cropping citra diamana bertujuan untuk mendeteksi perubahan citra pada wilayah pengamatan yang telah ditentukan antara citra referensi dengan citra setelah ada gerakan. Hasil dari proses deteksi perubahan citra dan cropping citra tersebut akan menjadi dasar untuk menentukan terdeteksi atau tidaknya perubahan citra pada video yang akan dimasukkan pada sistem. Sistem deteksi perubahan citra pada video yang diusulkan oleh penulis secara keseluruhan ditunjukan dalam diagram pada Gambar 1.

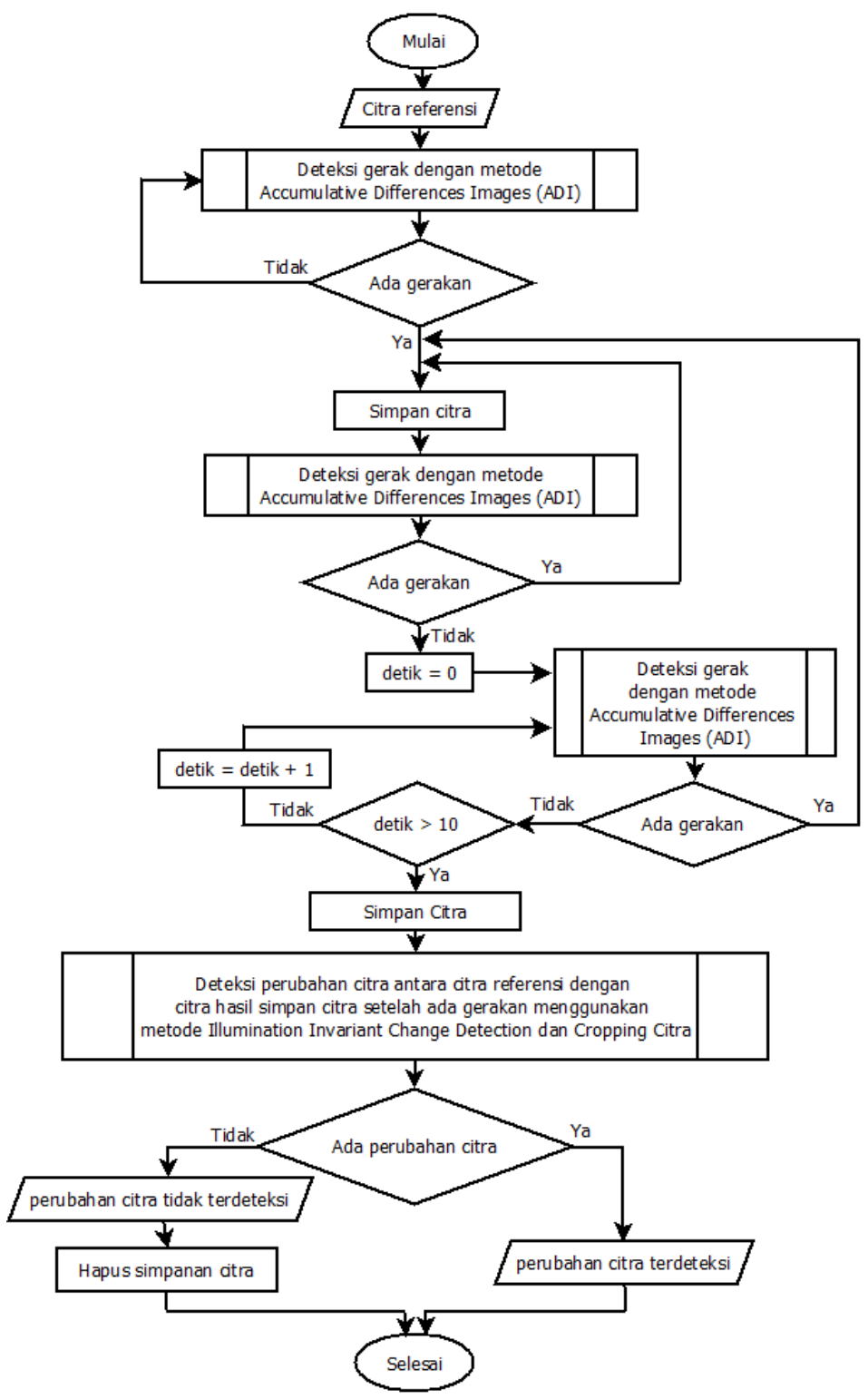

Gambar 1 Perancangan Sistem 
Gambar 1 telah ditunjukkan tahapan-tahapan dari deteksi perubahan citra pada video. Dimana terdapat dua tahapan dalam sistem yaitu tahapan deteksi gerak dan deteksi perubahan citra. Pada awalnya kamera webcam akan melakukan image capturing atau akuisisi citra.Citra yang dihasilkan pada proses akuisisi citra akan digunakan untuk proses deteksi gerak dengan menggunakan metode Accumulative Differences Images (ADI) dengan tahapan yang pertama adalah akuisisi citra yang akan dilakukan dan dijadikan citra referensi. Citra referensi merupakan citra yang tidak terdapat objek yang bergerak. Citra referensi dalam model warna RGB dikonversi ke dalam model warna grayscale. CCTV yang dihubungkan dengan komputer akan melakukan akuisisi video dan menghasilkan frame dari video secara berurutan dalam jangka waktu tertentu. Kumpulan frame yang diperoleh dari akuisisi citra dalam model warna RGB dikonversi ke dalam model warna grayscale. Beberapa citra warna grayscale kemudian dibandingkan dengan citra referensi dengan menggunakan metode ADI yang menghasilkan nilai akumulasi perbedaan antara citra referensi dan citra hasil akuisisi. Nilai akumulasi tersebut kemudian dibandingkan dengan suatu nilai threshold. Jika nilai akumulasi perbedaan antara citra referensi dan citra hasil akuisisi lebih besar dari threshold maka dinyatakan terdapat objek yang bergerak pada barisan citra tersebut. Jika gerakan tidak terdeteksi, sistem akan kembali melakukan akuisisi citra dan proses deteksi gerak dengan menggunakan metode ADI. Jika gerakan terdeteksi, sistem akan menyimpan citra dan kembali melakukan proses deteksi gerak dengan menggunakan metode ADI. Jika gerakan masih terdeteksi, maka sistem akan mengulangi proses menyimpan citra dan proses deteksi gerak dengan menggunakan metode ADI.

Jika gerakan tidak lagi terdeteksi selema 10 detik, sistem akan melakukan akuisisi citra dan membandingkan citra referensi (citra referensi baik berupa citra hasil image capturing atau citra yang didapat dari proses background modeling pada saat pengumpulan data) dengan citra hasil akuisisi citra setelah adanya gerakan dengan metode Illumination Invariant Change Detection yang dikombinasikan dengan metode cropping citra yang bertujuan untuk membatasi wilayah pengamatan. Metode Illumination Invariant Change Detection ini memiliki beberapa tahapan proses diantaranya adalah proses akuisisi citra, proses grayscale dimana hasilnya adalah citra yang memiliki kedalaman warna 8 bit (256 kombinasi warna keabuan) [10], proses $\log$ transformation, proses low-pass filters dengan Gaussian low-pass filters, proses pengurangan citra, proses exponential citra dan proses image subtraction. Gaussian low-pass filters dilakukan pada domain spasial dengan sebuah filter konvolusi atau convolution mask $h(i, j)$ yang digunakan sebagai kernel penapis (filter) pada proses konvolusi [11]. Hasilnya merupakan citra perbedaan antara citra referensi dengan cira setelah ada gerakan diaman sudah mengalami eliminasi komponen penyahayaannya. Jika perbedaan antara wilayah pengamatan pada citra referensi dengan wilayah pengamatan pada citra setelah terdapat gerakan lebih dari threshold, maka dapat disimpulkan perubahan citra telah terdeteksi.Jika perbedaan antara wilayah pengamatan pada citra referensi dengan wilayah pengamatan pada citra setelah terdapat gerakan kurang dari threshold, maka dapat disimpulkan perubahan citra tidak terdeteksi dan sistem akan menghapus hasil simpan citra pada sistem pada sesi tersebut.

Video simulasi diambil pada lingkungan yang memiliki beberapa kondisi diantaranya adalah ketinggian kamera dari lantai dasar adalah 3-4 meter, jarak kamera dari background adalah 4-5 meter, background dinding bersifat polos yaitu berwarna putih dan tidak bermotif, kondisi pencahayaan antara 129-65535 Lux untuk deteksi perubahan citra pada periode waktu antara jam 05.00 sampai jam 17.00 dan kondisi pencahayaan antara 10-2307 Lux untuk deteksi perubahan citra pada periode waktu antara jam 17.00 sampai jam 05.00, pengujian dilakukan pada bulan Oktober-November 2015 dan dalam kondisi tidak hujan, dan area tidak ramai dengan obyek yang bergerak (non-crowded scenes).

Adapun antar muka berjalannya deteksi perubahan citra pada video dapat dilihat dengan menggunakan metode Illumination Invariant Change Detection dapat ditunjukkan pada Gambar 2. 


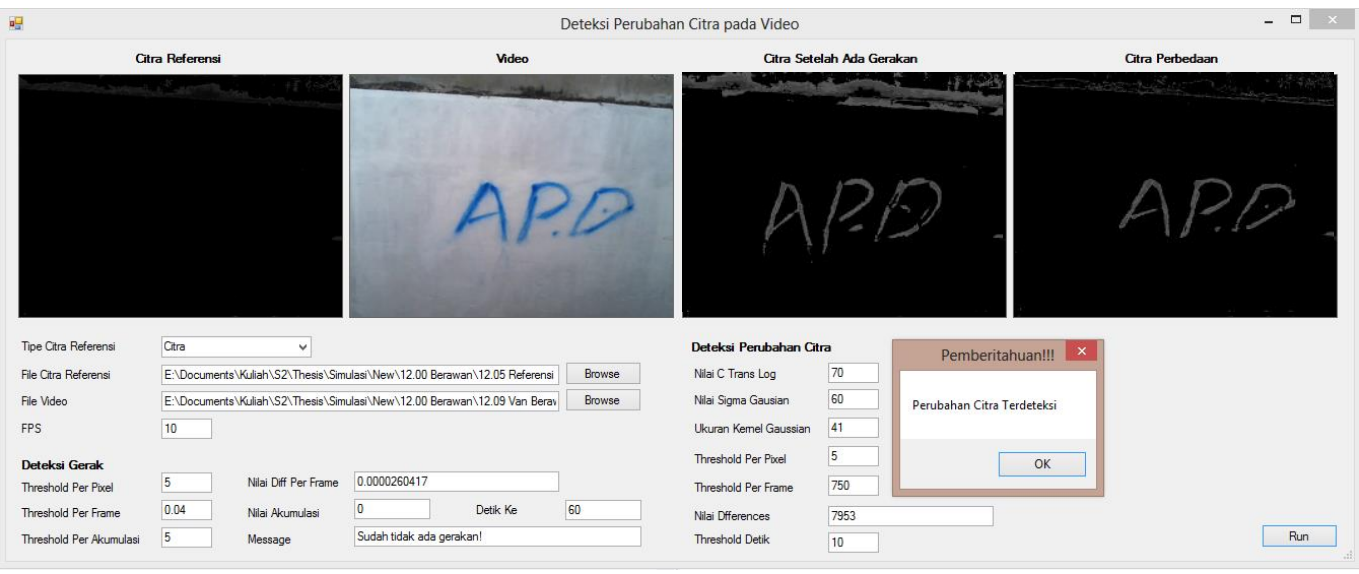

Gambar 2 Antar Muka Deteksi Perubahan Citra pada Video

\section{HASIL DAN PEMBAHASAN}

Pengujian deteksi gerak ini dilakukan dengan cara memilih berkas video simulasi yang akan diuji, menentukan threshold, dan menjalankan sistem dengan menekan tombol Proses. Untuk mengetahui keberhasilan sistem mendeteksi gerakan adalah dengan cara melihat informasi hasil deteksi gerak yang akan ditampilkan oleh sistem. Informasi hasil deteksi ditampilkan berdasarkan rentang waktu terjadinya perubahan gerakan. Mulai dari terdeteksinya gerakan sampai tidak lagi terdeteksi gerakan akan dihitung sebagai satu gerakan.

Untuk menentukan nilai threshold terbaik dilakukan dengan percobaan dengan memilih beberapa nilai threshold dan membandingkan hasilnya. Nilai threshold yang akan diuji adalah nilai threshold yang akan dibandingkan dengan besarnya nilai perbedaan antara dua frame. Hasil percobaan untuk menentukan nilai threshold yang akan digunakan terdapat pada Tabel 1.

Tabel 1 Hasil Percobaan dengan Threshold yang Berbeda pada Deteksi Gerak

\begin{tabular}{|c|c|l|}
\hline Nilai Threshold & Terdeteksi / Tidak & Keterangan \\
\hline 1 & Tidak & $\begin{array}{l}\text { Tidak terdeteksi adanya pergerakan karena motion level } \\
\text { kurang dari } 1\end{array}$ \\
\hline 0.5 & Tidak & $\begin{array}{l}\text { Tidak terdeteksi adanya pergerakan karena motion level } \\
\text { kurang dari } 0.5\end{array}$ \\
\hline 0.1 & Terdeteksi & $\begin{array}{l}\text { Terdeteksi adanya pergerakan karena motion level lebih } \\
\text { dari } 0.1\end{array}$ \\
\hline 0.05 & Terdeteksi & $\begin{array}{l}\text { Terdeteksi adanya pergerakan karena motion level lebih } \\
\text { dari } 0.05\end{array}$ \\
\hline 0.03 & Terdeteksi & $\begin{array}{l}\text { Terdeteksi adanya pergerakan karena motion level lebih } \\
\text { dari } 0.03\end{array}$ \\
\hline 0.02 & Terdeteksi & $\begin{array}{l}\text { Terdeteksi adanya pergerakan karena motion level lebih } \\
\text { dari } 0.02\end{array}$ \\
\hline 0.01 & Terdeteksi & $\begin{array}{l}\text { Terdeteksi adanya pergerakan karena motion level lebih } \\
\text { dari } 0.01\end{array}$ \\
\hline 0.005 & Terdeteksi & $\begin{array}{l}\text { Terdeteksi adanya pergerakan karena motion level lebih } \\
\text { dari } 0.005\end{array}$ \\
\hline
\end{tabular}

Nilai threshold yang telah ditentukan akan berpengaruh pada hasil deteksi gerak. Semakin kecil nilai threshold yang ditentukan maka perbedaan pixels antara dua frame yang diperoleh oleh sistem akan semakin besar. Jika perbedaan antara dua frame yang diperoleh oleh sistem semakin besar, maka nilai akumulasi akan bertambah sehingga akan memperbesar kemungkinan sistem mendeteksi adanya gerakan. Sebaliknya, semakin besar nilai threshold yang ditentukan maka perbedaan pixels antara dua frame yang diperoleh oleh sistem akan semakin kecil. Jika perbedaan antara dua frame yang diperoleh oleh sistem semakin kecil, maka nilai akumulasi 
tidak akan bertambah sehingga akan memperkecil kemungkinan sistem mendeteksi adanya gerakan.

Dari hasil pengujian pada Tabel 1 dapat disimpulkan bahwa pergerakan dapat terdeteksi jika nilai threshold berkisar antara 0.01 sampai dengan 0.005 , tetapi nilai yang tepat untuk menentukan gerakan adalah 0.03 sampai 0.05. Jika nilai threshold lebih kecil dari 0.02 perubahan yang lebih kecil seperti perubahan pencahayaan dan bayangan juga akan terdeteksi sebagai gerakan. Dengan demikian dapat disumpulkan nilai threshold yang akan digunakan dihitung dengan persamaan 4 .

$$
\text { NilaiThresholdDeteksiGerak }=\frac{0.03+0.05}{2}=0.04
$$

Maka dapat ditentukan nilai threshold yang tepat untuk mendeteksi gerakan pada sistem deteksi perubahan citra pada video ini adalah 0.04. Nilai threshold hasil percobaan ini akandigunakan sebagai salah satu variabel untuk melakukan deteksi gerak pada empat belas data video simulasi yang telah dilakukan sebelumnya.

Hasil percobaan yang dilakukan pada empat belas data video simulasi baik yang berisi maupun yang tidak berisi corat-coret dinding yang akan dijadikan dasar dari perhitungan precision, recall dan akurasi dari deteksi gerak dimana dilakukan dengan nilai threshold yang telah ditentukan dari perhitungan sebelumnya ditunjukan pada Tabel 2 .

Tabel 2 Akurasi Hasil Percobaan pada Deteksi Gerak

\begin{tabular}{|c|c|c|c|c|c|c|c|c|c|c|}
\hline No. & File Video & Durasi & $\mathbf{A}$ & B & $\mathrm{C}$ & D & $\mathbf{E}$ & $\mathbf{F}$ & $\mathbf{G}$ & $\mathbf{H}$ \\
\hline 1. & 05.40-NoVan.avi & 01.02 & 4 & 5 & 4 & 5 & 4 & 5 & 0 & 0 \\
\hline 2. & 05.43- Van.avi & 01.05 & 2 & 3 & 1 & 2 & 1 & 2 & 1 & 0 \\
\hline 3. & 10.08-NoVan.avi & 00.45 & 3 & 4 & 2 & 3 & 2 & 3 & 1 & 0 \\
\hline 4. & 10.11-Van.avi & 00.59 & 3 & 4 & 2 & 3 & 2 & 3 & 1 & 0 \\
\hline 5. & 10.58-NoVan.avi & 01.00 & 4 & 5 & 4 & 5 & 4 & 5 & 0 & 0 \\
\hline 6. & 11.01-Van.avi & 01.00 & 1 & 2 & 1 & 2 & 1 & 2 & 0 & 0 \\
\hline 7. & 12.07-NoVan.avi & 00.42 & 3 & 4 & 3 & 4 & 3 & 4 & 0 & 0 \\
\hline 8. & 12.09-Van.avi & 01.03 & 1 & 2 & 1 & 2 & 1 & 2 & 0 & 0 \\
\hline 9. & 15.49-NoVan.avi & 00.50 & 3 & 4 & 3 & 4 & 3 & 4 & 0 & 0 \\
\hline 10. & 15.51- Van.avi & 01.00 & 1 & 2 & 1 & 2 & 1 & 2 & 0 & 0 \\
\hline 11. & 17.50-NoVan.avi & 00.52 & 3 & 4 & 3 & 4 & 3 & 4 & 0 & 0 \\
\hline 12. & 17.54-Van.avi & 00.55 & 2 & 3 & 1 & 2 & 1 & 2 & 1 & 0 \\
\hline 13. & 21.00- NoVan.avi & 00.46 & 3 & 4 & 3 & 4 & 3 & 4 & 0 & 0 \\
\hline 14. & 21.28-Van.avi & 01.07 & 1 & 2 & 1 & 2 & 1 & 2 & 0 & 0 \\
\hline \multicolumn{3}{|c|}{ Jumlah } & 34 & 48 & 30 & 44 & 30 & 44 & 4 & 0 \\
\hline
\end{tabular}

Keterangan:

$\mathrm{A}=$ Jumlah deteksi gerak oleh sistem

$\mathrm{B}=$ Jumlah tidak terdeteksi gerak oleh sistem

$\mathrm{C}=$ Jumlah gerak seharusnya

$\mathrm{D}=$ Jumlah tidak terdeteksi gerak seharusnya

$\mathrm{E}=$ Jumlah deteksi gerak sama (true positif)

$\mathrm{F}=$ Jumlah tidak terdeteksi gerak sama (true negatif)

$\mathrm{G}=$ False positif

$\mathrm{H}=$ False negative

Menurut hasil gerakan yang dideteksi dengan benar oleh sistem yang menggunakan metode ADI, dapat dilakukan evaluasi pengujian dengan menggunakan perhitungan precision, recall, dan akurasi. Dengan evaluasi pengujian tersebut, didapatkan hasil perhitungan precision dan recall dari tahapan deteksigerak didapatkan nilai precision sebesar $88,24 \%$ dan nilai recall 100\%. Nilai akurasi yang didapat dari deteksi gerak sebesar 95,12\%.

Pengujian deteksi perubahan citra ini dilakukan dengan cara memilih citra referensi yang berasal dari capture citra atau dari video diamana akan dilakukan proses background extraction 
dengen metode Running Average (RA) sehingga akan menghasilkan citra referensi. Metode RA bertujuan untuk memperkirakan background dari video atau kumpulan frame yang di dalamnya terdapat obyek yang bergerak dengan cara menghitung jumlah bobot current background dan current frame untuk iterasi selanjutnya [12]. Citra referensi yang diambil dari video dilakukan apabila lingkungan pengambilan citra referensi merupkan lingkungan yang memiliki banyak gerakan. Selanjutnya pengguna memilih citra setelah ada gerakan untuk masing-masing video simulasi yang akan diuji, menentukan threshold, dan menjalankan sistem dengan menekan tombol Proses.

Untuk mengetahui keberhasilan sistem mendeteksi perubahan citra adalah dengan cara melihat informasi hasil deteksi perubahan citra yang akan ditampilkan oleh sistem. Informasi hasil deteksi ditampilkan berdasarkan besarnya nilai perbedaan antara citra referensi dengan citra setelah ada gerakan yang kemudian dibandingkan dengan nilai threshold.

Untuk menentukan nilai threshold terbaik dilakukan dengan percobaan dengan memilih beberapa nilai threshold dan membandingkan hasilnya. Nilai threshold yang akan diuji adalah nilai threshold yang akan dibandingkan dengan besarnya nilai perbedaan antara citra referensi dengan citra setelah ada gerakan untuk semua data pengujian berupa video simulasi. Hasil percobaan untuk menentukan nilai threshold yang akan digunakan terdapat pada Tabel 3.

Tabel 3 Hasil Percobaan dengan Threshold yang Berbeda pada Deteksi Perubahan Citra

\begin{tabular}{|c|l|l|l|}
\hline A & \multicolumn{1}{|c|}{ B } & \multicolumn{1}{c|}{ C } & \multicolumn{1}{c|}{ D } \\
\hline 5000 & $\begin{array}{l}\text { Tidak } \\
\text { Sesuai }\end{array}$ & Sesuai & $\begin{array}{l}\text { Sistem tidak mendeteksi adanya perubahan pada semua video simulasi } \\
\text { baik yang sebenarnya tidak ada perubahan maupupun yang sebenarnya } \\
\text { ada perubahan }\end{array}$ \\
\hline 3000 & $\begin{array}{l}\text { Tidak } \\
\text { Sesuai }\end{array}$ & Sesuai & $\begin{array}{l}\text { Sistem tidak mendeteksi adanya perubahan pada semua video simulasi } \\
\text { baik yang sebenarnya tidak ada perubahan maupupun yang sebenarnya } \\
\text { ada perubahan }\end{array}$ \\
\hline 1000 & Sesuai & Sesuai & $\begin{array}{l}\text { Sistem mendeteksi adanya perubahan pada hampir semua video simulasi } \\
\text { baik yang sebenarnya ada perubahan maupupun yang sebenarnya tidak } \\
\text { ada perubahan }\end{array}$ \\
\hline 100 & Sesuai & Sesuai & $\begin{array}{l}\text { Sistem mendeteksi adanya perubahan pada hampir semua video simulasi } \\
\text { baik yang sebenarnya ada perubahan maupupun yang sebenarnya tidak } \\
\text { ada perubahan }\end{array}$ \\
\hline
\end{tabular}

Keterangan:

A = Nilai threshold

$\mathrm{B}=$ Video yang berisi corat-coret (terdapat perubahan citra)

$\mathrm{C}=$ Video yang tidak berisi corat-coret (tidak terdapat perubahan citra)

$\mathrm{D}=$ Keterangan

Nilai threshold yang telah ditentukan akan berpengaruh pada hasil deteksi perubahan citra. Semakin kecil nilai threshold yang ditentukan maka nilai perbedaan antara citra referensi dengan citra setelah ada gerakan yang diperoleh oleh sistem akan semakin dianggap memiliki perbedaan. Sebaliknya, semakin besar nilai threshold yang ditentukan maka nilai perbedaan antara citra referensi dengan citra setelah ada gerakan yang diperoleh oleh sistem akan semakin tidak dianggap memiliki perbedaan.

Dari hasil pengujian pada Tabel 3 dapat disimpulkan bahwa nilai threshold yang sesuai untuk semua data pengujian berupa video simulasi baik yang berisi aksi corat-coret dinding maupun tidak berisi aksi corat-coret dinding adalah berkisar antara 500 - 1000. Dengan demikian dapat disumpulkan nilai threshold yang akan digunakan adalah dihitung dengan persamaan 5 .

$$
\text { NilaiThresholdDeteksiPerubahanCitra }=\frac{500+1000}{2}=750
$$


Maka dapat ditentukan nilai threshold untuk mendeteksi perubahan citra untuk masukan video simulasi pada sistem deteksi perubahan citra pada video ini adalah 750 . Nilai threshold hasil percobaan ini akan digunakan sebagai salah satu variabel untuk melakukan deteksi perubahan citra pada empat belas video simulasi yang telah dilakukan sebelumnya.

Hasil percobaan yang dilakukan pada empat belas data video simulasi baik yang berisi maupun yang tidak berisi corat-coret dinding yang akan dijadikan dasar dari perhitungan precision, recall dan akurasi dari deteksi perubahan citra dimana dilakukan dengan nilai threshold yang telah ditentukan dari perhitungan sebelumnya ditunjukan pada Tabel 4.

Tabel 4 Akurasi Hasil Percobaan pada Deteksi Perubahan Citra

\begin{tabular}{|l|l|l|l|l|l|}
\hline No. & File Video & Perbedaan & Deteksi Sistem & Deteksi Seharusnya & Kesimpulan \\
\hline 1. & 05.40-NoVan.avi & 487 & Tidak & Tidak & True Negatif \\
\hline 2. & 05.43- Van.avi & 9350 & Ya & Ya & True Positif \\
\hline 3. & $10.08-$ NoVan.avi & 318 & Tidak & Tidak & True Negatif \\
\hline 4. & $10.11-$ Van.avi & 2749 & Ya & Ya & True Positif \\
\hline 5. & $10.58-N o V a n . a v i$ & 268 & Tidak & Tidak & True Negatif \\
\hline 6. & $11.01-V a n . a v i$ & 6811 & Ya & Ya & True Positif \\
\hline 7. & $12.07-N o V a n . a v i$ & 60 & Tidak & Tidak & True Negatif \\
\hline 8. & $12.09-$ Van.avi & 7953 & Ya & Ya & True Positif \\
\hline 9. & $15.49-$ NoVan.avi & 1336 & Ya & Tidak & False Positif \\
\hline 10. & $15.51-$ Van.avi & 7030 & Ya & Ya & True Positif \\
\hline 11. & $17.50-$ NoVan.avi & 471 & Tidak & Tidak & True Negatif \\
\hline 12. & $17.54-V a n . a v i$ & 5965 & Ya & Ya & True Positif \\
\hline 13. & $21.00-$ NoVan.avi & 203 & Tidak & Tidak & True Negatif \\
\hline 14. & $21.28-V a n . a v i$ & 10770 & Ya & Ya & True Positif \\
\hline
\end{tabular}

Menurut hasil perubahan citra yang dideteksi dengan benar oleh sistem yang menggunakan metode Illumination Invariant Change Detection, dapat dilakukan evaluasi pengujian dengan menggunakan perhitungan precision, recall, dan akurasi. Dengan evaluasi pengujian tersebut, didapatkan hasil perhitungan precision dan recall dari tahapan deteksi perubahan citra dengan metode Illumination Invariant Change Detection pada data video simulasi yang telah dilakukan didapatkan nilai precision sebesar $87,5 \%$ dan nilai recall $100 \%$. Nilai akurasi yang didapat dari deteksi perubahan citra dengan metode Illumination Invariant Change Detection pada data video simulasi yang telah dilakukan adalah sebesar 92,86\%.

\section{KESIMPULAN}

Berdasarkan hasil penelitian yang dilakukan terhadap sistem deteksi perubahan citra pada video dengan metode Illumination Invariant Change Detection, maka dapat diperoleh kesimpulan sebagai berikut:

1. Evaluasi sistem dalam mendeteksi gerak dengan metode Accumulative Difference Image (ADI) yang dilakukan pada data video simulasi didapatkan nilai precision sebesar $88.24 \%$, dan nilai recall sebesar $100 \%$, dengan akurasi $95.12 \%$.

2. Evaluasi sistem dalam mendeteksi perubahan citra dengan metode Illumination Invariant Change Detection yang dikombinasikan dengan metode cropping citra untuk mengeliminasi bagian dari citra yang tidak termasuk bagian dari wilayah pengamatanyang dilakukan pada data video simulasi didapatkan nilai precision sebesar $87.5 \%$, dan nilai recall sebesar $100 \%$, dengan akurasi $92.86 \%$.

\section{SARAN}

Berdasarkan hasil dan kesimpulan yang diperoleh, maka dapat diberikan saran untuk penelitian selanjutnya. Adapun saran-saran untuk penelitian selanjutnya adalah sebagai berikut:

1. Melakukan penelitian dengan metode pengolahan citra digital yang lain untuk mendeteksi gerak dan untuk mendeteksi perubahan citra. Dengan metode pengolahan citra digital yang 
lain dimungkinkan kekurangan yang terdapat pada deteksi perubahan citra dengan menggunakan metode Illumination Invariant Change Detection dapat teratasi sehingga sistem dapat memberikan hasil dengan tingkat akurasi yang lebih baik.

2. Dimungkinkan untuk melakukan penelitian dengan menggunakan metode yang berbeda untuk mengatasi kekurangan sistem yaitu metode lain yang lebih dinamis untuk membatasi wilayah pengamatan dari citra (region of interest) dan metode lain yang dapat membedakan antara coret-coretan pada dinding dengan objek yang berhenti lama yang bukan hasil aksi corat-coret pada wilayanh pengamatan sistem.

3. Melakukan penelitian deteksi perubahan citra pada video pada objek dinding yang berbeda dan dengan posisi kamera yang berbeda.

4. Mengembangkan sistem deteksi perubahan citra pada video ini menjadi sistem deteksi vandalisme yang mampu membedakan corat-coretan pada dinding yang bersifat legal dengan corat-coretan pada dinding yang bersifat ilegal atau sering disebut sebagai aksi vandalisme.

\section{UCAPAN TERIMA KASIH}

Penulis mengucapkan terima kasih kepada Allah SWT karena atas limpahan rahmatNya, penulis dapat menyelesaikan peneletian ini dengan baik. Penulis juga mengucapkan terima kasih kepada keluarga, bapak/ibu dosen, teman-teman, dan pihak-pihak yang telah memberi dukungan demi suksesnya penelitian ini.

\section{DAFTAR PUSTAKA}

[1]Gonzalez, R.C. \& Woods, R.E., 2008. Digital Image Processing. 3rd ed. New Jersey: Prentice-Hall,Inc.

[2]Martin, E.M. \& Pobil, A.P., 2012. Robust Motion Detection in Real-Life Scenarios. 1st ed. New York: Springer.

[3]Cappelletta, L., \& Harte, N., 2010, Nostril Detection for Robust Mouth Tracking, IET Irish Signals and Systems Conference(ISSC 2010), pp. 239-244, 2010.

[4]Kendo, T., 2010, A Moving Object Extraction Method Using Accumulative Intensity and Texture Differences, International Symposium on Communications and Information Technologies (ISCIT), Tokyo, pp. 1002-1006, 2010.

[5]Toth, D., Aach, T., \& Metzler, V., 2000, Illumination-Invariant Change Detection, 4th IEEE Southwest Symposium on Image Analysis and Interpretation, Austin, pp. 3-7, 2000.

[6]Liu, Q., Sun, M., Sclabassi, R.J., 2004, Illumination-Invariant Change Detection Model for Patient Monitoring Video, 26th Annual International Conference of the IEEE Engineering in Medicine and Biology Society, San Francisco, pp. 1782-1785, 2004.

[7]Sacchi, C., Regazzoni, C., \& Vernazza, G., 2001, A Neural Network-Based Image Processing System for Detection of Vandal Acts in Unmanned Railway Environments, Proc. 11th International Conf. on Image Analysis and Processing, Palermo, pp. 529-534, 2001.

[8]Angiati, D., Gera, G., Piva, S., \& Regazzoni, C.S., 2005, A Novel Method for Graffiti Detection Using Change Detection Algorithm, IEEE Conf. on Advanced Video and Signal Based Surveillance, pp. 242-246, 2005.

[9]Ghazal, M., Vazquez, C., \& Amer, A., 2007, Real-time Automatic Detection of Vandalism Behavior in Video Sequences, ISIC. IEEE Conf. on Systems, Man and Cybernetics, Montreal, Que, pp. 1056-1060, 2007.

[10]Putra, D., 2010. Pengolahan Citra Digital. 1st ed. Yogyakarta: Penerbit ANDI.

[11]Dawson, K. \& Howe, 2014. A Practical Introduction to Computer Vision With OpenCV. 1st ed. Chichester: John Wiley \& Sons Ltd.

[12]Laganiere, R., 2011. OpenCV 2 Computer Vision Application Programming Cookbook. 1st ed. Birmingham: Packt Publishing Ltd. 